\title{
Rejuvenating of Kidney Tissues on Alloxan Induced Diabetic Mice under the Effect of Momordica charantia
}

\author{
Bhaskar Sharma, ${ }^{1}$ Mohd. Sufiyan Siddiqui, ${ }^{1}$ Gurudayal Ram, ${ }^{2}$ Ranjeet Kumar Yadav, \\ Arti Kumari, ${ }^{3}$ Gaurav Sharma, ${ }^{4}$ and Nakuleshwar Dut Jasuja ${ }^{4}$ \\ ${ }^{1}$ Department of Biochemistry \& Bioprocess Technology, Sam Higginbottom Institute of Agriculture, Technology \& Sciences, Allahabad, \\ Uttar Pradesh 211008, India \\ ${ }^{2}$ Department of Molecular \& Cellular Engineering, Sam Higginbottom Institute of Agriculture, Technology \& Sciences, Allahabad, \\ Uttar Pradesh 211008, India \\ ${ }^{3}$ PG of Zoology, A.N. College, Patna, Bihar 800013, India \\ ${ }^{4}$ School of Science, Suresh Gyan Vihar University, Jaipur, Rajasthan 302017, India
}

Correspondence should be addressed to Bhaskar Sharma; reserachpaper26@gmail.com

Received 2 April 2014; Revised 14 May 2014; Accepted 18 May 2014; Published 15 June 2014

Academic Editor: Hidetaka Akita

Copyright (C) 2014 Bhaskar Sharma et al. This is an open access article distributed under the Creative Commons Attribution License, which permits unrestricted use, distribution, and reproduction in any medium, provided the original work is properly cited.

\begin{abstract}
Diabetes mellitus is a chronic disorder in human and responsible for different complications and also causes mortality and morbidity. A wide number of herbal products are employed in the treatment of diabetes for their better efficacy and safety compared to synthetic medicine. The present studies have established the antidiabetic potential and rejuvenating capacity of kidney tissues under the effect of extract. Diabetes was induced in the Swiss albino mice by injecting alloxan at the dose of $150 \mathrm{mg} / \mathrm{kg}$ body weight and aqueous extract of Momordica charantia fruits at doses of $100 \mathrm{mg} / \mathrm{kg}$ body weight and $250 \mathrm{mg} / \mathrm{kg}$ body weight was administered orally for three weeks. After 21 days of treatment of the aqueous extracts of Momordica charantia significantly reduces serum glucose level, kidney function tests, lipid peroxidation as well as histopathological study also did show adverse alternation in the morphological architecture of the kidney tissue. Thus, from this study we concluded that Momordica charantia exhibited significant antihyperglycemic and rejuvenating capacity of kidney tissues activities in alloxan induced diabetic mice.
\end{abstract}

\section{Introduction}

Diabetes mellitus (DM) is possibly the world's fastest growing metabolic disorder and as the knowledge of the heterogeneity of this disorder increases so does the need for more appropriate therapies [1]. DM is a pathologic condition, resulting in severe metabolic imbalances and nonphysiologic changes in many tissues, where oxidative stress plays an important role in the aetiology $[1,2]$. Diabetes is associated with the generation of reactive oxygen species (ROS) which cause oxidative damage, particularly to heart, kidney, eyes, nerves, liver, small and large blood vessels, and immunological and gastrointestinal system $[1,3]$.

Diabetic nephropathy (DN) is one of the important microvascular complications of diabetes mellitus. Recent studies indicate that reactive oxygen species (ROS) play a key intermediate role in the pathophysiology of diabetic nephropathy [4]. Hyperglycaemia, the main determinant of the initiation and progression of diabetic nephropathy, not only generates more reactive oxygen metabolites but also attenuates antioxidative mechanisms through nonenzymatic glycosylation of antioxidant enzymes [1]. The mechanism by which hyperglycaemia causes free radical generation and thus causes oxidative stress is complex. High glucose concentration directly increases hydrogen peroxide production by murine mesangial cells and lipid peroxidation of glomeruli and glomerular mesangial cells [5]. Hyperglycaemia promotes glycosylation of circulating and cellular protein and may initiate a series of autooxidative reactions that culminate in the formation and accumulation of advanced glycosylation end-products (AGE) in tissue proteins [6, 7]. The AGE has oxidizing potential and can promote tissue damage by free radicals. In addition, increased lipid peroxidation impairs membrane functions by decreasing membrane fluidity and changing the activity of membrane-bound enzymes and receptors. Its products (lipid radicals and lipid peroxides) 
are harmful to the cells in the body and associated with atherosclerosis and damage to brain, kidney, liver, and other tissues $[1,8]$. In addition, diabetes and hyperglycemia can be sources of DNA damage via the oxidation of DNA bases and sugar phosphate binding sites [9]. The occurrence of these alterations can result in mutagenic effects and DNA replication arrest and could be associated with risks for developing cancer in diabetes mellitus patients $[10,11]$.

Medicinal plants have long been used for the treatment of DM. The disease was continued to manage entirely with such indigenous plants until the development of insulin injection therapy in 1921 [12]. Several such plants have been identified as hypoglycemic either individually or in combination [13, 14]. Momordica charantia, also known as bitter melon, bitter gourd, or balsam pear, is a plant widely cultivated in many tropical and subtropical regions of the world and is frequently used in South Asia and the Orient as a food stuff and medicinal plant. Extracts from various components of this plant have been reported to possess hypoglycaemic activity [15]. Thus, bitter melon can be an alternative therapy used for lowering glucose level in diabetic patients [16]. The hypoglycemic activity of Momordica charantia fruit juice is demonstrated in animals with experimental diabetes and also in humans in both type 1 and type 2 diabetes mellitus [17]. Scientists have identified 3 groups of constituents thought to be responsible for blood sugar lowering action of bitter melon; one of these is a compound called charantin which is composed of $\beta$ sitosterol-glucoside and 2-5-stigmatadien-3- $\beta$-ol-glucoside and can potentially replace treatment by insulin [18]. Another compound, polypeptide-p (plant insulin), found in seeds and fruits of bitter melon is similar to insulin in composition, so it can be of a great benefit in therapy of type 1 diabetes [19]. Third compound is alkaloids which have also been noted to have a blood sugar lowering effect. Compounds known as oleanolic acid glycosides have been found to improve glucose tolerance in type 2 diabetes [20].

\section{Materials and Methods}

2.1. Collection of Plant Material. The fruits of M. charantia were collected from local market, Allahabad, Uttar Pradesh, India. The plant species was authenticated by Botanist, Department of Botany, Sam Higginbottom Institute of Agriculture, Technology \& Sciences, Allahabad, Uttar Pradesh, India. The fruits were shade dried with occasional shifting, then powdered with mechanical grinder passing through sieve, and stored in air-tight container.

2.2. Preparation of Extracts. After shade drying the dried fruits were powdered in mechanical grinder. The powdered fruit was macerated with distilled water for $72 \mathrm{hrs}$ at room temperature with occasional stirring. It was then filtered through filter paper, and the filtrate was dried and stored in refrigerator for further use. During experiment the crude extract was diluted with distilled water just before administration to animals.

2.3. Chemicals. All chemicals were obtained from the following sources: alloxan was purchased from the Loba Chemie,
Mumbai. Commercially available kits for biochemical analyses such as glucose, urea, and creatinine were done using commercial diagnostic kits following manufacturer's instructions. All reagents used in study were of analytical grade.

2.4. Maintenance of Animals and Approval of Protocol. Healthy Swiss albino mice (Mus musculus) (4-6 months old, weighing 28-32 g) were used for the present investigation. They were housed in a clean polypropylene cage and maintained in an air-conditioned experimental room at 12-hour light: dark cycles. The animals were acclimatized to laboratory condition for one week prior to experiment. Standard pellets were used as a basal diet during the experimental period. The control and experimental animals were provided with purified drinking water ad libitum. The animals were maintained in accordance with the "CPCSEA guidelines for laboratory animal facility" (Committee for the Purpose of Control and Supervision on Experiments on Animals) and the approval number is CPCSEA Registration. number $1129 /$ bc/07/CPCSEA, dated 13/02/2008. Before starting the experiment the animals were carefully marked on different parts of their body, which was later used as identification mark for a particular animal, so that the response of a particular mouse prior to and after the administration could be noted separately.

2.5. Acute Oral Toxicity Studies. Momordica charantia at the dose range of $100-2500 \mathrm{mg} / \mathrm{kg}$ body weight were administered by oral gavage method on different group of mice comprised of 6 mice in each group. Animals were kept under close observation for 4 hours after administering the fraction for behavior, neurological, and autonomic profile and then observed for any change in the general behavior and/or physical activities; mortality was recorded within 72 hours. Acute toxicity was determined according to the method of Lorke [21].

2.6. Induction of Diabetes in Experimental Animals. Diabetes mellitus was induced in overnight fasted mice by a single intraperitoneal injection of alloxan monohydrates at the rate of $150 \mathrm{mg} / \mathrm{kg}$ body weight [22]. The animals were allowed free access to $5 \%$ glucose solution to overcome the drug induced hypoglycaemia. Blood glucose level of these mice was estimated $72 \mathrm{hr}$ after alloxan administration, and diabetes was confirmed by blood samples collected from the tip of the tail using a blood glucometer (Accu Sure, Taiwan). Animals with blood glucose level equal to or more than $200 \mathrm{mg} / \mathrm{dL}$ were declared diabetic and were used in entire experimental group [23].

2.7. Animal Grouping and Treatment Schedule. Four groups of mice, six mice in each, received the following treatment schedule:

Group I: normal control (A);

Group II: diabetic control (B) (alloxan $150 \mathrm{mg} / \mathrm{kg}$ body weight i.p.);

Group III: diabetic control (B) (alloxan $150 \mathrm{mg} / \mathrm{kg}$ body weight i.p.) + C (Momordica charantia) (fruit extract at the dose of $100 \mathrm{mg} / \mathrm{kg}$ body weight); 
Group IV: diabetic control (B) (alloxan $150 \mathrm{mg} / \mathrm{kg}$ body weight i.p.) + D (Momordica charantia) (fruit extract at the dose of $250 \mathrm{mg} / \mathrm{kg}$ body weight).

\subsection{Collection of Blood Sample and Estimation of Serum} Biochemical Investigations. After the last dose, animals were fasted for 12 hours and sacrificed. Blood samples were collected by orbital sinus puncture method [24]. Serum was prepared following procedure. Briefly, blood samples were withdrawn from orbital sinus using nonheparinised capillary tubes, collected in dried centrifuge tubes, and allowed to clot. Serum was separated from the clot by centrifuging at $3000 \mathrm{rpm}$ for $15 \mathrm{~min}$ at room temperature. Serum was collected carefully and kept at $-20^{\circ} \mathrm{C}$ until analysis of fasting blood glucose concentration was determined by commercially available glucose kit (crest coral clinical system, Goa, India) based on Trinder [25]. Kidney function tests including determination of urea [26], uric acid [27], albumin [28], protein [29], and creatinine [30] in serum were done using diagnostic kits (crest coral clinical system, Goa, India). Lipid peroxidation was estimated by Ohkawa et al. [31]

2.9. Body Weight and Kidney Weight. The body weight of mice of each group was measured just before and 21 days after MC (Momordica charantia). Kidney weights were measured after posttreatment sacrifice.

2.10. Histopathological Studies. At the end of the experimental period, the whole kidney tissues from each animal were removed after sacrificing the animal by cervical dislocation and a portion of the kidney was cut into two to three pieces of approximately $6 \mathrm{~mm}^{3}$ sizes and fixed for $48 \mathrm{~h}$ in $10 \%$ formalin saline were dehydrated by passing successfully in different mixture of ethyl alcohol-water, cleaned in xylene and embedded in paraffin wax. Thin sections of $5 \mu \mathrm{m}$ thickness of kidney tissue were cut and then stained with haematoxylin and eosin dye (H\&E), which mounted in neutral deparaffinized xylene (DPX) medium for microscopic observation. The thin sections of kidney were made into permanent slides and examined [32] under high resolution microscope with photographic facility and photomicrographs were taken.

2.11. Statistical Analysis. Data from the experiments were presented as mean \pm standard deviation. Statistical analysis was done by using the GraphPad Prism Program (GraphPad Software, Inc., San Diego, USA). Paired $t$-test was done to see any difference between the paired groups. The level of significance was set at $P<0.001$.

\section{Results}

3.1. Body and Organs Weight. The body and organ weight (kidney) of control and experimental group were given in Table 1. The total body weight decreased as well as kidney weight during diabetes, when compared with control mice $(P<0.001)$. Oral administration of aqueous extract (100 mg/kg body weight and $250 \mathrm{mg} / \mathrm{kg}$ body weight) significantly improved.
TABLE 1: Effect of Momordica charantia on body weight and kidney weight in alloxan induced diabetic mice.

\begin{tabular}{lccc}
\hline \multirow{2}{*}{ Treatment } & \multicolumn{2}{c}{ Body weight $(\mathrm{gm})$} & \multirow{2}{*}{ Kidney weight $(\mathrm{gm})$} \\
& Initial & Final & \\
\hline A & $30.33 \pm 1.63$ & $32 \pm 2.6$ & $1.11 \pm 0.15$ \\
B & $29 \pm 1.78^{\wedge}$ & $18 \pm 2.36^{\wedge}$ & $0.88 \pm 0.09^{\wedge}$ \\
C & $28.16 \pm 1.47^{*}$ & $29.83 \pm 2.92^{*}$ & $1.03 \pm 0.08^{*}$ \\
D & $28.50 \pm 1.64^{*}$ & $30.70 \pm 1.42^{*}$ & $1.10 \pm 0.71^{*}$ \\
\hline
\end{tabular}

The value represented as means \pm S.D for six mice per group. ${ }^{\wedge} P<0.001$ compared to normal group and ${ }^{*} P<0.001$ compared to diabetic group. A: normal control, B: diabetic control, C: Momordica charantia fruit extract at the dose of $100 \mathrm{mg} / \mathrm{kg}$ body weight, and D: Momordica charantia fruit extract at the dose of $250 \mathrm{mg} / \mathrm{kg}$ body weight.

3.2. Serum Glucose Level. After induction of diabetes by alloxan, diabetes was confirmed by the presence of hyperglycemia in animals and the mean level of glucose in the control group of mice was evaluated to be $77.67 \pm 12.03 \mathrm{mg} / \mathrm{dL}$ (range: 60-95), whereas it was $222.5 \pm 25.64 \mathrm{mg} / \mathrm{dL}$ (range values: 190 to $260, P=0.0001$, and $t=13.96$ ) in alloxanized group. After the treatment of mice with the fruit extract of Momordica charantia (100 mg/kg body weight) the glucose level decreased down to $180 \pm 22.52 \mathrm{mg} / \mathrm{dL}(P=0.0123$, $t=3.82$ ) having a range of $156-220 \mathrm{mg} / \mathrm{dL}$ and more potent effect at the dose of $250 \mathrm{mg} / \mathrm{kg}$ body weight of extract and the level of glucose also significantly decreased to $112.3 \pm$ $14.04 \mathrm{mg} / \mathrm{dL}(P=0.0003, t=8.90)$ having range of $90-$ $129 \mathrm{mg} / \mathrm{dL}$. These variations in glucose concentrations are evident from Figure 1. The significant increase in glucose concentration in the diabetic animals compared to that of the control mice is evident on alloxanization. However, the oral administration of aqueous extract of Momordica charantia significantly reduced the glucose level in serum when compared with alloxan induced diabetic mice.

3.3. Serum Urea Level. In control group of mice urea activity was found to be $14.81 \pm 1.99 \mathrm{mg} / \mathrm{dL}$ having the range of 12 to $17.85 \mathrm{mg} / \mathrm{dL}$. In diabetics, its activity got raised to $28 \pm$ $4.60 \mathrm{mg} / \mathrm{dL}(P=0.0006, t=7.71)$ with variations ranging from 22 to 35 . However, extract (100 and $250 \mathrm{mg} / \mathrm{kg}$ body weight) treatment of this group for three weeks resulted in decrease of urea activity to $23 \pm 3.79$ and $16.67 \pm 2.48$ $(P=0.0449, t=2.66$ and $P=0.0034, t=5.20)$ having values ranging from 19 to $30 \mathrm{mg} / \mathrm{dL}$ and 13 to $20 \mathrm{mg} / \mathrm{dL}$. These variations are depicted by the box plot in Figure 2 .

3.4. Serum Uric Acid. In control group of mice uric acid activity was found to be $4.13 \pm 1.17 \mathrm{mg} / \mathrm{dL}$ having the range of 2.35 to $5.63 \mathrm{mg} / \mathrm{dL}$. In diabetics, its activity got raised to $12.34 \pm 1.86 \mathrm{mg} / \mathrm{dL}(P=0.0001, t=12.17)$ with variations ranging from 10 to 15 . However, extract (100 and $250 \mathrm{mg} / \mathrm{kg}$ body weight) treatment of this group for three weeks resulted in decrease of uric acid activity to $7.22 \pm 1.61$ and $5.01 \pm 1.15(P=0.0052, t=4.73$ and $P=0.0008$, $t=7.14$ ) having values ranging from 4.98 to $9.65 \mathrm{mg} / \mathrm{dL}$ and 3.56 to $6.98 \mathrm{mg} / \mathrm{dL}$. The overall alterations in these groups are shown in Figure 3. 


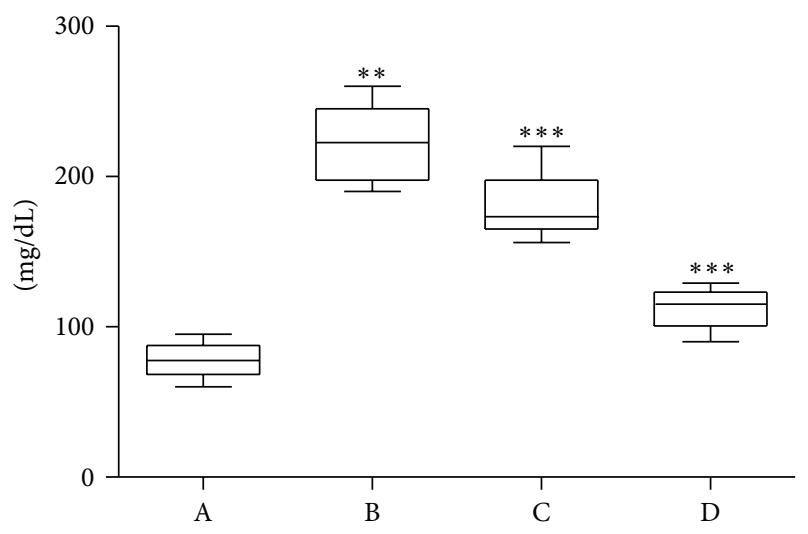

FIGURE 1: Effect of aqueous extract of C and D (100 and $250 \mathrm{mg} / \mathrm{kg}$ body weight) on the serum glucose levels in alloxan induced mice. Values are the means \pm S.D. for six animals in each group. Values are significant at $P<0.001$; statistical significance was compared within groups as follows. ${ }^{* *}$ Diabetic mice were compared with normal mice. ${ }^{* * *} \mathrm{C}$ and $\mathrm{D}$ treated diabetic mice were compared with diabetic mice.

3.5. Serum Creatinine Level. The estimation of serum creatinine level in control group revealed its level to be $0.55 \pm$ $0.11 \mathrm{mg} / \mathrm{dL}$ with individual level variations ranging from 0.42 to $0.72 \mathrm{mg} / \mathrm{dL}$. In alloxan treated diabetic group, the mean value was $1.32 \pm 0.155 \mathrm{mg} / \mathrm{dL}$ with individual level variations ranging from 1.11 to $1.55 \mathrm{mg} / \mathrm{dL}$, whereas, in extract treated at dose of $100 \mathrm{mg} / \mathrm{kg}$ body weight, the mean value was $0.93 \pm$ $0.11 \mathrm{mg} / \mathrm{dL}$ of the values ranging from 0.79 to $1.10 \mathrm{mg} / \mathrm{dL}$ and, at dose of $250 \mathrm{mg} / \mathrm{kg}$ body weight, its mean value was 0.77 $\pm 0.17 \mathrm{mg} / \mathrm{dL}$ with ranging from 0.54 to 0.98 . This showed a significant increase $(P=0.0002, t=10.22)$ when compared with control group; however, the decline in extract treated level was significant $(P=0.0074, t=4.34$ and $P=0.0017$, $t=6.14$ ) compared to alloxan treated group (Figure 4).

3.6. Serum Albumin Level. In control group of mice albumin activity was found to be $4.01 \pm 1.26 \mathrm{~g} / \mathrm{dL}$ having the range of 2.35 to $5.80 \mathrm{~g} / \mathrm{dL}$. In diabetics, its activity got declined to 2.44 $\pm 0.48 \mathrm{~g} / \mathrm{dL}(P=0.0240, t=3.20)$ with variations ranging from 1.69 to 3.05 . However, extract (100 and $250 \mathrm{mg} / \mathrm{kg}$ body weight) treatment of this group for three weeks resulted in increase of albumin activity to $3.46 \pm 0.72$ and $3.05 \pm 0.67$ $(P=0.0189, t=3.41$ and $P=0.1145, t=1.91)$ having values ranging from 2.35 to $4.23 \mathrm{~g} / \mathrm{dL}$ and 2.09 to $3.88 \mathrm{~g} / \mathrm{dL}$. These variations along with statistical significance are depicted by box plot as shown in Figure 5 .

3.7. Serum Protein Level. In control group of mice protein activity was found to be $6.33 \pm 1.86 \mathrm{~g} / \mathrm{dL}$ having the range of 4 to $9 \mathrm{~g} / \mathrm{dL}$. In diabetics, its activity got declined to $4.01 \pm$ $0.62 \mathrm{~g} / \mathrm{dL}(P=0.0071, t=4.39)$ with variations ranging from 3.09 to 5.01 . However, extract (100 and $250 \mathrm{mg} / \mathrm{kg}$ body weight) treatment of this group for three weeks resulted in increase of protein levels to $4.73 \pm 1.37$ and $5.45 \pm 1.16(P=$ $0.0804, t=2.18$ and $P=0.0240, t=3.20$ ) having values ranging from 3.090 to $6.980 \mathrm{~g} / \mathrm{dL}$ and 3.85 to $7.24 \mathrm{~g} / \mathrm{dL}$. These variations along with statistical significance are depicted by box plot as shown in Figure 6.

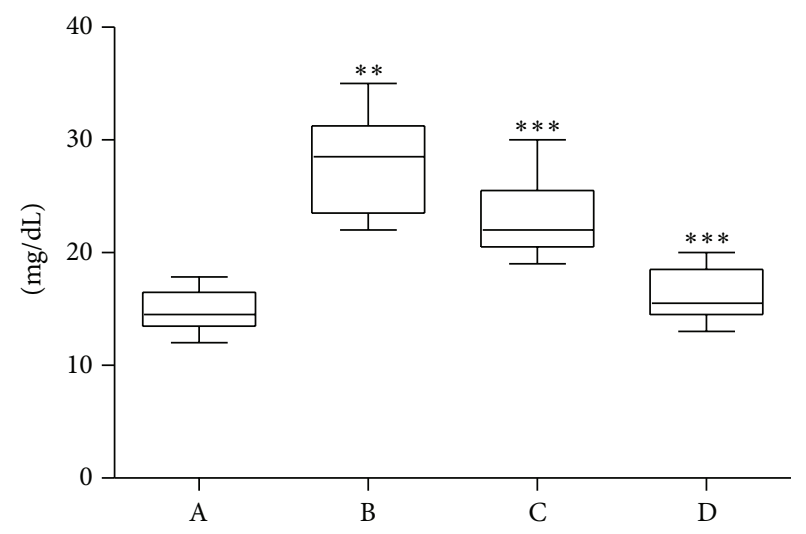

Figure 2: Effect of aqueous extract of C and D (100 and $250 \mathrm{mg} / \mathrm{kg}$ body weight) on the serum urea levels in alloxan induced mice. Values are the means \pm S.D. for six animals in each group. Values are significant at $P<0.001$; statistical significance was compared within groups as follows. ${ }^{* *}$ Diabetic mice were compared with normal mice. ${ }^{* * *} \mathrm{C}$ and $\mathrm{D}$ treated diabetic mice were compared with diabetic mice.

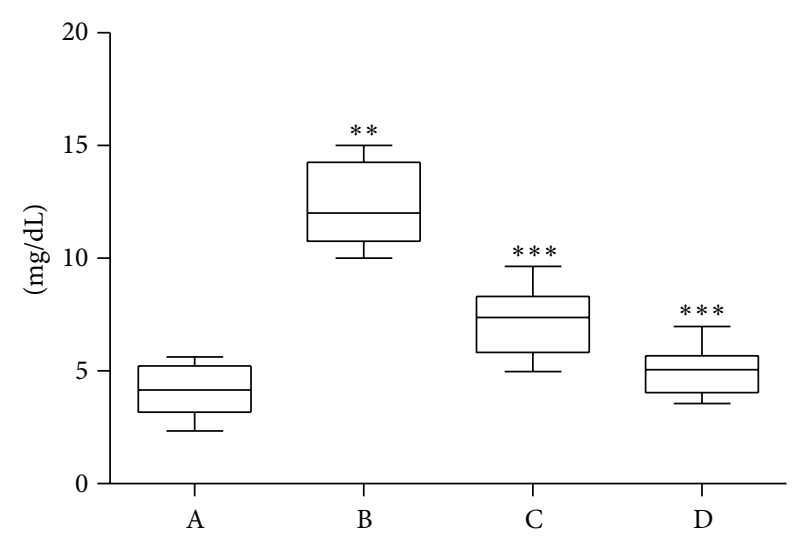

FIGURE 3: Effect of aqueous extract of C and D (100 and $250 \mathrm{mg} / \mathrm{kg}$ body weight) on the serum uric acid levels in alloxan induced mice. Values are the means \pm S.D. for six animals in each group. Values are significant at $P<0.001$; statistical significance was compared within groups as follows. ${ }^{* *}$ Diabetic mice were compared with normal mice. ${ }^{* * *} \mathrm{C}$ and $\mathrm{D}$ treated diabetic mice were compared with diabetic mice.

3.8. Serum Lipid Peroxidation Activity. The estimation of serum lipid peroxidation level in control group revealed its level to be $1.19 \pm 0.11 \mathrm{nmole} / \mathrm{mL}$ with individual level variations ranging from 1.02 to $1.35 \mathrm{mg} / \mathrm{dL}$. In alloxan treated diabetic group, the mean value was $2.14 \pm 0.18 \mathrm{nmole} / \mathrm{mL}$ with individual level variations ranging from 1.87 to 2.38 nmole $/ \mathrm{mL}$, whereas in extract treated at dose of $100 \mathrm{mg} / \mathrm{kg}$ body weight the mean value was $1.68 \pm 0.33 \mathrm{nmole} / \mathrm{mL}$ of the values ranging from 1.29 to $2.15 \mathrm{nmole} / \mathrm{mL}$ and at dose of $250 \mathrm{mg} / \mathrm{kg}$ body weight its mean value was $1.33 \pm 0.10$ nmole/mL with ranging from 1.19 to 1.49 . This showed a significant increase $(P=0.0001, t=13.68)$ when compared with control group; however, the decline in extract treated level was significant $(P=0.0231, t=3.23$ and $P=0.0001$, $t=13.21$ ) compared to alloxan treated group (Figure 7). 


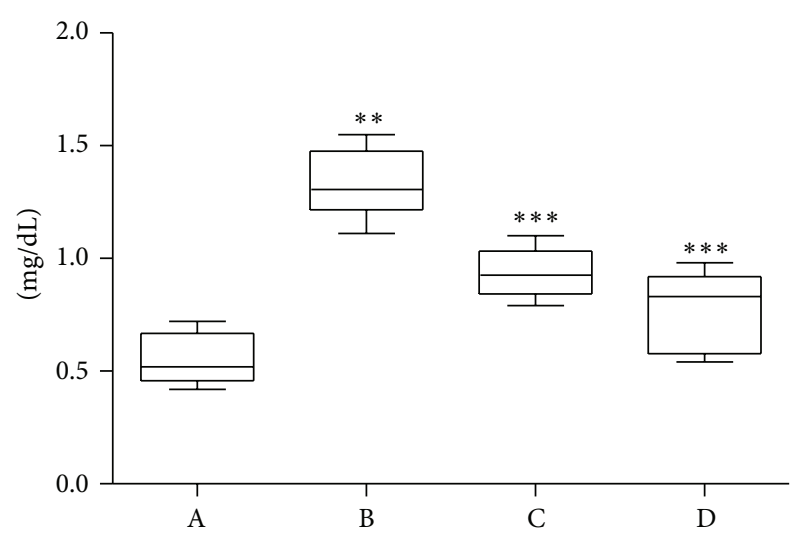

Figure 4: Effect of aqueous extract of C and D (100 and $250 \mathrm{mg} / \mathrm{kg}$ body weight) on the serum creatinine levels in alloxan induced mice. Values are the means \pm S.D. for six animals in each group. Values are significant at $P<0.001$; statistical significance was compared within groups as follows. ${ }^{* *}$ Diabetic mice were compared with normal mice. ${ }^{* * *} \mathrm{C}$ and $\mathrm{D}$ treated diabetic mice were compared with diabetic mice.

3.9. Histopathology Study. Figures 8 and 9 showed that histological study of kidney of control mice showed well rejuvenated renal corpuscles (glomerulus and Bowman's capsule) with normal proximal and distal convoluted tubules but in case of diabetic mice showed severe degeneration, in addition to proximal and distal convoluted tubules; alloxan also caused degeneration in glomerulus with increased capsular space, whereas treatment of diabetic mice with aqueous extract of Momordica charantia caused marked regeneration in kidney histoarchitecture. Oral Momordica charantia administration rejuvenated proximal and distal convoluted tubules with well-regenerated glomerulus and Bowman's capsule (Figure 10).

\section{Discussion}

Medicinal plants being the potential sources of bioactive agents are gaining acceptability worldwide. A number of studies on ethnomedicinal plants and herbal medicines have been conducted in the past and plants have been reported for being used for medicinal purpose by tribals in several countries. The ethnobotanical survey can bring out many different clues for the development of drugs to treat human diseases like diabetes. Safe, effective, and inexpensive indigenous remedies are gaining popularity equally among the people of both the urban and rural areas, especially in developing countries like India [33].

In this study, Momordica charantia was selected for anti diabetic study and rejuvenating capacity of tissues. Therefore, the study was undertaken to justify its claimed use. Alloxan is most commonly used to induce diabetes in animals.

Alloxan is a $\beta$-cytotoxin and induces diabetes mellitusby damaging the insulin secreting $\beta$-cells of the pancreas, resulting in decreased endogenous insulin release. Alloxanadministered rabbits become hyperglycemic in a short period of time, followed by hepatic glucose overproduction [34]. High ambient glucose can promote apoptosis, suggested

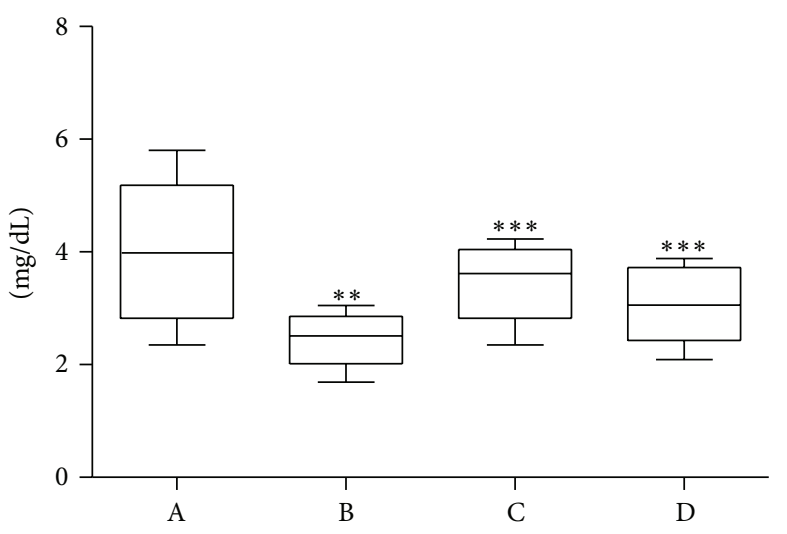

FIGURE 5: Effect of aqueous extract of C and D (100 and $250 \mathrm{mg} / \mathrm{kg}$ body weight) on the serum albumin levels in alloxan induced mice. Values are the means \pm S.D. for six animals in each group. Values are significant at $P<0.001$; statistical significance was compared within groups as follows. ${ }^{* *}$ Diabetic mice were compared with normal mice. ${ }^{* * *} \mathrm{C}$ and $\mathrm{D}$ treated diabetic mice were compared with diabetic mice.

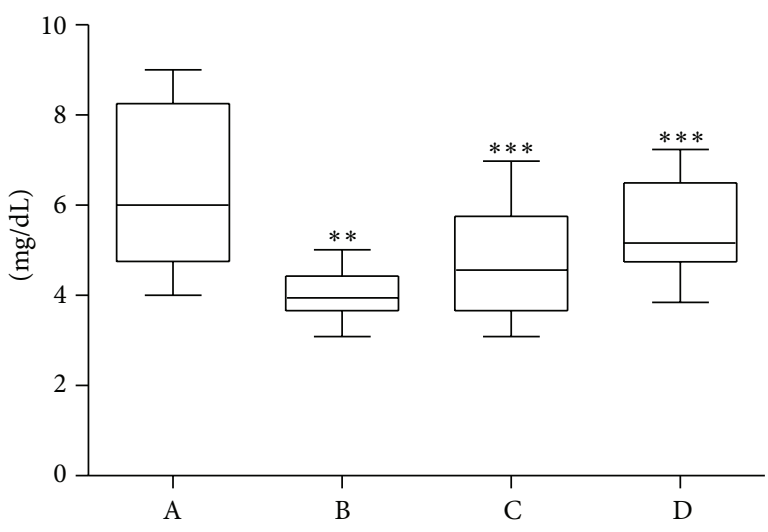

FIGURE 6: Effect of aqueous extract of C and D (100 and $250 \mathrm{mg} / \mathrm{kg}$ body weight) on the serum protein levels in alloxan induced mice. Values are the means \pm S.D. for six animals in each group. Values are significant at $P<0.001$; statistical significance was compared within groups as follows. ${ }^{* *}$ Diabetic mice were compared with normal mice. ${ }^{* * *} \mathrm{C}$ and $\mathrm{D}$ treated diabetic mice were compared with diabetic mice.

by [35] causing potential cellular damage as a result of hyperglycemia in diabetes. Reactive oxygen species (ROS) are important mediators of $\beta$-cell death during the development of DM. High glucose has been postulated to generate ROS and nitrogen species in numerous cell types. Generation of superoxide by high glucose is well described and arises principally viathe mitochondrial electron transport chain [36]. Another source of glucose induced oxidative stress is viathe polyol pathway where glucose is reduced to sorbitol by aldose reductase in a process that consumes NADPH. This will impair the NADPH-dependent generation of glutathione, an essential cellular antioxidant [37].

In this study significant hyperglycemia was achieved after alloxan $(150 \mathrm{mg} / \mathrm{kg}$ body weight $)$ injection. Alloxan induced diabetic mice with more than $200 \mathrm{mg} / \mathrm{dL}$ of blood glucose 


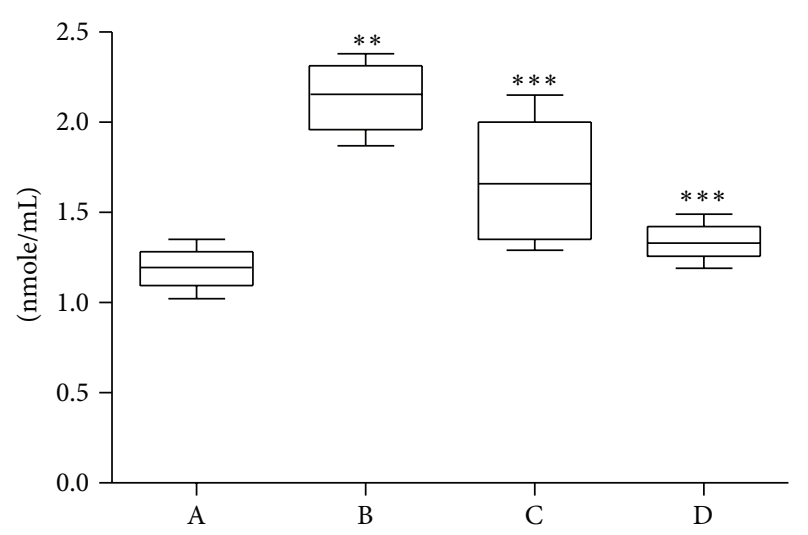

FIgURE 7: Effect of aqueous extract of C and D (100 and $250 \mathrm{mg} / \mathrm{kg}$ body weight) on the serum lipid peroxidation levels in alloxan induced mice. Values are the means \pm S.D. for six animals in each group. Values are significant at $P<0.001$; statistical significance was compared within groups as follows. ${ }^{* *}$ Diabetic mice were compared with normal mice. ${ }^{* * *} \mathrm{C}$ and $\mathrm{D}$ treated diabetic mice were compared with diabetic mice.

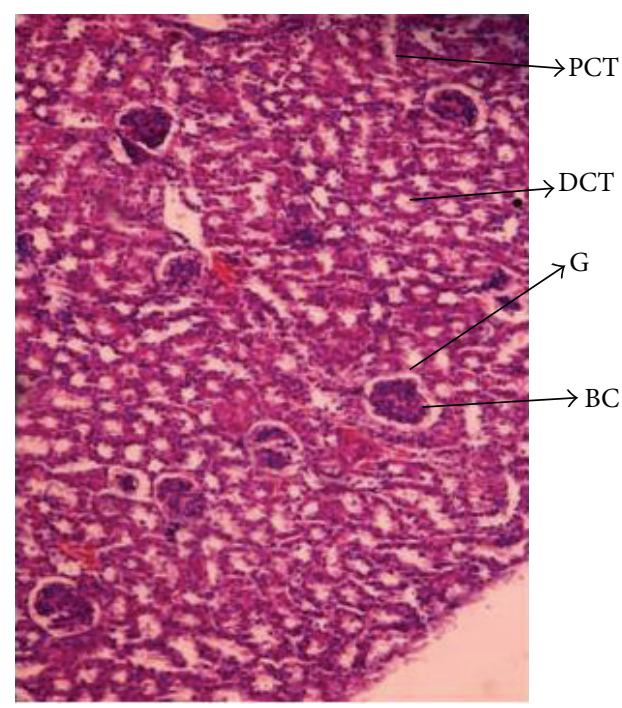

FIGURE 8: Photomicrograph of control mice kidney section (day 21) showing normal histoarchitecture with well-developed proximal and distal convoluted tubules (PCT, DCT) and normal glomerulus and Bowman's capsule ( $\mathrm{G}$ and $\mathrm{BC}$ ).

level were considered to be diabetic and used for the study. However, administration of the aqueous extract at the dose of 100 and $250 \mathrm{mg} / \mathrm{kg}$ body weight decreased the glucose level in alloxan induced mice. These results are in accordance with the findings of $[16,38-40]$. Such an effect may be accounted for in part by a decrease in the rats of intestinal glucose absorption achieved by an extra pancreatic action including the stimulation of peripheral glucose utilization or enhancing glycolytic and glycogenic process with concomitant decrease in glycogenolysis and gluconeogenesis [41]. Effective blood glucose control is the key for preventing or reversing diabetic complications and improving the quality of life in patients with diabetes. On this basis we have selected the glucose induced hyperglycaemic model to screen the antihyperglycaemic activity of the plant extracts.

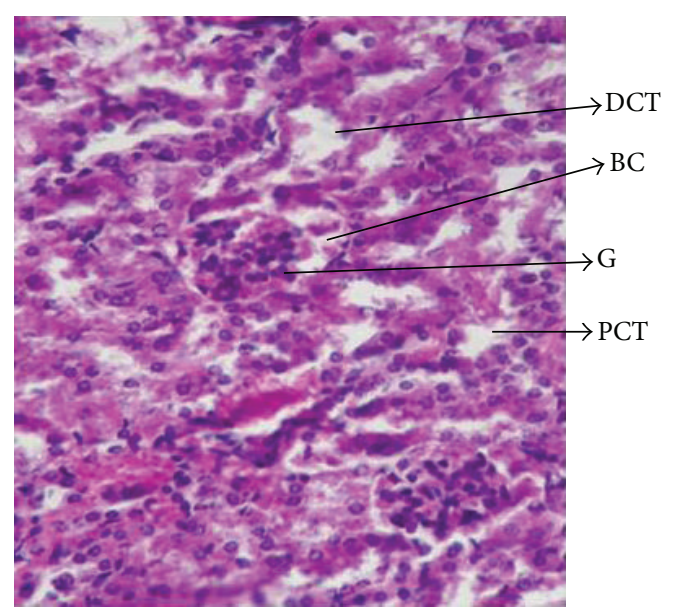

FIGURE 9: Photomicrograph of diabetic mice kidney section (day 21) showing degenerated glomerulus with distorted proximal and distal convoluted tubules.

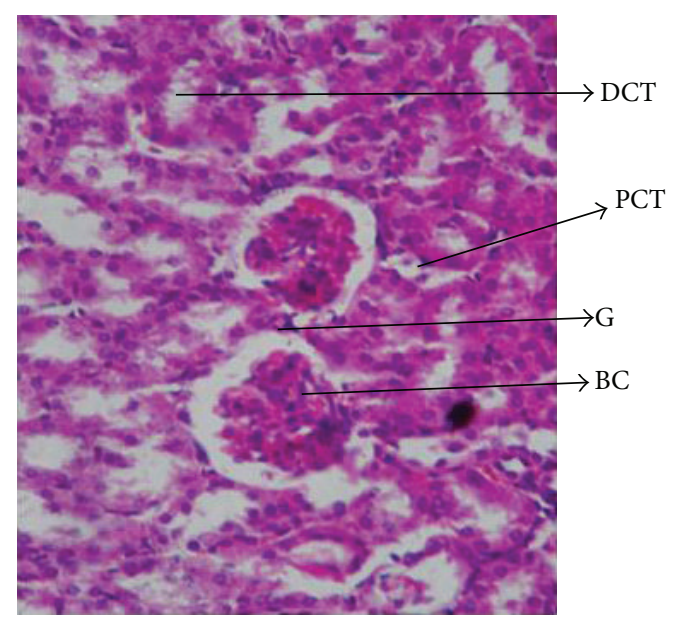

FIGURE 10: Photomicrograph of mice kidney section aqueous extract of Momordica charantia showing well-rejuvenated proximal and distal convoluted tubules with glomerulus and Bowman's capsule.

The present study evaluated the changes in body weight and organs weight in control diabetic induced and treated animals for the entire period of the study as decrease in body weight is considered as a marker for the development of diabetes due to continuous excretion of glucose and decrease in peripheral uptake of glucose and glycogen synthesis [42]. Our results indicated a considerable change in body and organs weight between alloxan induced and treated mice. These results are in agreement with the findings of $[38,39]$ but contradictory with Dans et al. [43] who found that Momordica charantia had no significant effect on body weight of diabetics. This increase in body weight of diabetic rats as a result of Momordica charantia treatment may be ascribed to the increase in insulin release.

Our results showed that alloxanization caused significant increase in serum uric acid, urea, and creatinine and decrease in level of albumin and protein values in diabetic animals when compared with nondiabetic control. This may be due to the protein glycation in diabetes which may lead to 
muscle wasting and increased release of purine. This may be due to the protein glycation in diabetes which may lead tomuscle wasting and increased release of purine, the main source of uric acid, as well as increased activity of xanthine oxidase. Our results are consistent with those reported by others [44-46] who showed that serum uric acid, urea, and creatinine levels were increased in diabetic rats. This may due to metabolic disturbance in diabetes reflected in high activities of xanthine oxidase, lipid peroxidation, and increased triacylglycerol and cholesterol levels. Similar results were reported [47] showing the increased concentrations of urea and creatinine due to excessive lipolysis in severe diabetes mellitus leading to ketosis and later on to acidosis. Kidney maintains optimum chemical composition of body fluid by acidification of urine and removal of metabolic wastes such as urea, uric acid, and creatinine. During renal diseases the concentration of these metabolites increases in blood [48]. On the other hand treatment of aqueous extract of Momordica charantia for 21 days on diabetic mice, the elevated level were become normalize [49-51].

In this regard, the decrease of serum albumin and protein in diabetic animals was restored to control rate by insulin treatment, which accelerates amino acid transport through cells and stimulates the protein manufacturing machinery of the cell [52]. Reduction in plasma albumin was observed in alloxan induced mice which may be due to microproteinuria and albuminuria, which is an important clinical marker of diabetic nephropathy [53-55], and/or may be due to increased protein catabolism [56]. Lack of insulin also reduces RNA and mRNA, which is another factor for the reduction of total protein [57]. Our results also correlate with the above findings.

Lipid peroxides are the secondary products of oxidative stress and are unleashed as a result of the toxic effect of reactive oxygen species produced during lipid peroxidation in diabetes[58]. Lipid peroxidation (LPO) is one of the cellular features of chronic diabetes. In diabetes, it is thought that hypoinsulinemia increases the activity of the enzyme, fatty acyl coenzyme-A oxidase, which initiates beta-oxidation of fatty acids, resulting in LPO [59]. Increased LPO impairs membrane function by decreasing membrane fluidity and changing the activity of membrane-bound enzymes and receptors [60]. LPO will in turn result in elevated production of free radicals that are harmful to cells in the body [61]. Moreover, lipid peroxide mediated tissue damage has been observed in the development of both types I and II diabetes mellitusand insulin secretion is closely associated with lipoxygenase-derived peroxides. The increased LPO leads to cellular infiltration and islet cell damage in diabetes[62]. During this study, elevated levels of lipid peroxidation were noticed in alloxan treated mice. There are several reports in the literature that demonstrated the elevated levels of lipid peroxides in the alloxan induced diabetes[63]. This normalization may be accomplished by the antioxidant and free radical quenching nature of Momordica charantia.

\section{Conclusion}

Data from the present study clearly indicate that the aqueous extract of the fruit at $250 \mathrm{mg} / \mathrm{kg}$ body weight dose exhibited significant antihyperglycemic than at low dose $(100 \mathrm{mg} / \mathrm{kg}$ body weight) in the induced diabetic mice, various biochemical parameters like KFT as well as regeneration of kidney tissues. Therefore, further investigation is necessary to determine the exact phytoconstituent responsible for antidiabetic effect.

\section{Conflict of Interests}

The authors declare that there is no conflict of interests regarding the publication of this paper.

\section{Acknowledgments}

Authors are thankful to Director of Mahavir Cancer Sansthan \& Research Centre, Patna, Bihar, India, for providing required facilities for the current study. The authors also thank Head of the department for providing the animals for the present work.

\section{References}

[1] N. Orsolic and I. Basic, "Honey bee products and their polyphenolic compounds in treatment of diabetes," in Phytopharmacology and Therapetutic Values IV, J. N. Govil and V. K. Singh, Eds., vol. 22, pp. 455-471, Stadium Press, 2008.

[2] K. K. M. Yue, W.-S. Chung, A. W. N. Leung, and C. H. K. Cheng, "Redox changes precede the occurrence of oxidative stress in eyes and aorta, but not in kidneys of diabetic rats," Life Sciences, vol. 73, no. 20, pp. 2557-2570, 2003.

[3] I. G. Obrosova, A. G. Minchenko, R. Vasupuram et al., "Aldose reductase inhibitor fidarestat prevents retinal oxidative stress and vascular endothelial growth factor overexpression in streptozotocin-diabetic rats," Diabetes, vol. 52, no. 3, pp. 864871, 2003.

[4] H. Ha, I.-A. Hwang, J. H. Park, and H. B. Lee, "Role of reactive oxygen species in the pathogenesis of diabetic nephropathy," Diabetes Research and Clinical Practice, vol. 82, no. 1, pp. S42S45, 2008.

[5] L. M. Ruiz-Muñoz, F. Vidal-Vanaclocha, and I. Lampreabe, "Enalaprilat inhibits hydrogen peroxide production by murine mesangial cells exposed to high glucose concentrations," Nephrology Dialysis Transplantation, vol. 12, no. 3, pp. 456-464, 1997.

[6] J. V. Hunt, M. A. Bottoms, and M. J. Mitchinson, "Oxidative alterations in the experimental glycation model of diabetes mellitus are due to protein-glucose adduct oxidation: some fundamental differences in proposed mechanisms of glucose oxidation and oxidant production," Biochemical Journal, vol. 291, no. 2, pp. 529-535, 1993.

[7] M. Anjaneyulu and K. Chopra, "Effect of irbesartan on the antioxidant defence system and nitric oxide release in diabetic rat kidney," American Journal of Nephrology, vol. 24, no. 5, pp. 488496, 2004.

[8] K. K. M. Yue, S.-N. Leung, P.-M. Man et al., "Alterations in antioxidant enzyme activities in the eyes, aorta and kidneys of diabetic rats relevant to the onset of oxidative stress," Life Sciences, vol. 77, no. 7, pp. 721-734, 2005.

[9] N. Oršolić, G. Gajski, V. Garaj-Vrhovac, D. Crossed D Signikić, Z. Š. Prskalo, and D. Sirovina, "DNA-protective effects of 
quercetin or naringenin in alloxan-induced diabetic mice," European Journal of Pharmacology, vol. 656, no. 1-3, pp. 110-118, 2011.

[10] J. C. Will, F. Vinicor, and E. E. Calle, "Is diabetes mellitus associated with prostate cancer incidence and survival?" Epidemiology, vol. 10, no. 3, pp. 313-318, 1999.

[11] P. Maisonneuve, L. Agodoa, R. Gellert et al., "Cancer in patients on dialysis for end-stage renal disease: an international collaborative study," The Lancet, vol. 354, no. 9173, pp. 93-99, 1999.

[12] N. Wadood, M. Nisar, A. Rashid, A. Wadood, and A. Khan, "Effect of a compound recipe (medicinal plants) on serum insulin levels of alloxan induced diabetic rabbits," Journal of Ayub Medical College, Abbottabad, vol. 19, no. 1, pp. 32-38, 2007.

[13] W. D. Winters, Y. S. Huo, and D.-L. Yao, "Inhibition of the progression of type 2 diabetes in the C57BL/6J mouse model by an anti-diabetes herbal formula," Phytotherapy Research, vol. 17, no. 6, pp. 591-598, 2003.

[14] N. Wadood, A. Wadood, and M. Nisar, "Effect of Ficus relegiosa on blood glucose and total lipid levels of normal and alloxan diabetic rabbits," Journal of Ayub Medical College, Abbottabad, vol. 15, no. 4, pp. 40-42, 2003.

[15] E. H. Karunanayake and K. H. Tennekoon, "Search of novel hypoglycaemic agents from medicinal plants," in Diabetes Mellitus and Its Complications-An Update, A. K. Sharma, Ed., pp. 192-196, Macmillan, India, 2003.

[16] A. P. Jayasooriya, M. Sakono, C. Yukizaki, M. Kawano, K. Yamamoto, and N. Fukuda, "Effects of Momordica charantia powder on serum glucose levels and various lipid parameters in rats fed with cholesterol-free and cholesterol- enriched diets," Journal of Ethnopharmacology, vol. 72, no. 1-2, pp. 331-336, 2000.

[17] J. Welihinda, E. H. Karunanayake, M. H. R. Sheriff, and K. S. A. Jayasinghe, "Effect of Momordica charantia on the glucose tolerance in maturity onset diabetes," Journal of Ethnopharmacology, vol. 17, no. 3, pp. 277-282, 1986.

[18] J. Pitipanapong, S. Chitprasert, M. Goto, W. Jiratchariyakul, M. Sasaki, and A. Shotipruk, "New approach for extraction of charantin from Momordica charantia with pressurized liquid extraction," Separation and Purification Technology, vol. 52, no. 3, pp. 416-422, 2007.

[19] A. Paul and S. S. Raychaudhuri, "Medicinal uses and molecular identification of two Momordica charantia varieties - a review," Electronic Journal of Biology, vol. 6, no. 2, pp. 43-51, 2010.

[20] H.-L. Cheng, H.-K. Huang, C.-I. Chang, C.-P. Tsai, and C.-H. Chou, "A cell-based screening identifies compounds from the stem of Momordica charantia that overcome insulin resistance and activate AMP-activated protein kinase," Journal of Agricultural and Food Chemistry, vol. 56, no. 16, pp. 6835-6843, 2008.

[21] D. Lorke, "A new approach to practical acute toxicity testing," Archives of Toxicology, vol. 54, no. 4, pp. 275-287, 1983.

[22] T. Szkudelski, "The mechanism of alloxan and streptozotocin action in B cells of the rat pancreas," Physiological Research, vol. 50, no. 6, pp. 537-546, 2001.

[23] S. Lenzen, "The mechanisms of alloxan- and streptozotocininduced diabetes," Diabetologia, vol. 51, no. 2, pp. 216-226, 2008.

[24] H. Van Herck, V. Baumans, C. J. W. M. Brandt et al., "Orbital sinus blood sampling in rats as performed by different animal technicians: the influence of technique and expertise," Laboratory Animals, vol. 32, no. 4, pp. 377-386, 1998.

[25] P. Trinder, "Determination of glucose in blood using glucoseoxidase with an alternative oxygen acceptor," Annals of Clinical Biochemistry, vol. 6, pp. 24-27, 1969.
[26] J. K. Fawcett and J. E. Scott, "A rapid and precise method for the determination of urea," Journal of Clinical Pathology, vol. 13, pp. 156-159, 1960.

[27] P. Fossati, L. Prencipe, and G. Berti, "Use of 3,5-dichloro-2-hydroxybenzenesulfonic acid/4-aminophenazone chromogenic system in direct enzymic assay of uric acid in serum and urine," Clinical Chemistry, vol. 26, no. 2, pp. 227-231, 1980.

[28] B. T. Doumas, W. Ard Watson, and H. G. Biggs, "Albumin standards and the measurement of serum albumin with bromcresol green," Clinica Chimica Acta, vol. 31, no. 1, pp. 87-96, 1971.

[29] O. H. Lowry, N. J. Rosehmugh, A. L. Farr, and R. J. Randall, "Protein measurement with the Folin phenol reagent," The Journal of Biological Chemistry, vol. 193, no. 1, pp. 265-275, 1951.

[30] R. W. Bonsnes and H. H. Taussky, "On the colorimetric determination of Creatinine by the Jaffe reaction," The Journal of Biological Chemistry, vol. 158, pp. 581-591, 1945.

[31] H. Ohkawa, N. Ohishi, and K. Yagi, "Assay for lipid peroxides in animal tissues by thiobarbituric acid reaction," Analytical Biochemistry, vol. 95, no. 2, pp. 351-358, 1979.

[32] D. E. Kleiner, E. M. Brunt, M. Van Natta et al., "Design and validation of a histological scoring system for nonalcoholic fatty liver disease," Hepatology, vol. 41, no. 6, pp. 1313-1321, 2005.

[33] S. S. Katewa, B. L. Chaudhary, and A. Jain, "Folk herbal medicines from tribal area of Rajasthan, India," Journal of Ethnopharmacology, vol. 92, no. 1, pp. 41-46, 2004.

[34] K. Rajagopal and K. Sasikala, "Antihyperglycaemic and antihyperlipidaemic effects of Nymphaea stellata in alloxan-induced diabetic rats," Singapore Medical Journal, vol. 49, no. 2, pp. 137$141,2008$.

[35] D. A. Allen, S. Harwood, M. Varagunam, M. J. Raftery, and M. M. Yaqoob, "High glucose-induced oxidative stress causes apoptosis in proximal tubular epithelial cells and is mediated by multiple caspases," The FASEB Journal, vol. 17, no. 8, pp. 908910, 2003.

[36] S. S. Chung, E. C. Ho, K. S. Lam, and S. K. Chung, "Contribution of poloyl pathway to diabetes-induced oxidative stress," Journal of the American Society of Nephrology, vol. 14, no. 8, pp. 233-236, 2003.

[37] M. M. Dallak, P. D. Mikhailidis, A. M. Haidara et al., "Oxidative stress as a common mediator for apoptosis induced-cardiac damage in diabetic rats," The Open Cardiovascular Medicine Journal, vol. 2, pp. 70-78, 2008.

[38] N. P. C. Fernandes, C. V. Lagishetty, V. S. Panda, and S. R. Naik, "An experimental evaluation of the antidiabetic and antilipidemic properties of a standardized Momordica charantia fruit extract," BMC Complementary and Alternative Medicine, vol. 7, article 29, 2007.

[39] X.-Q. Yuan, X.-H. Gu, J. Tang, and J. Wasswa, "Hypoglycemic effect of semipurified peptides from Momordica charantia L. var. Abbreviata Ser. in alloxan-induced diabetic mice," Journal of Food Biochemistry, vol. 32, no. 1, pp. 107-121, 2008.

[40] P. Chaturvedi, S. George, M. Milinganyo, and Y. B. Tripathi, "Effect of Momordica charantia on lipid profile and oral glucose tolerance in diabetic rats," Phytotherapy Research, vol. 18, no. 11, pp. 954-956, 2004.

[41] P. Luzi, M. A. Rafi, T. Victoria, G. B. Baskin, and D. A. Wenger, "Characterization of the rhesus monkey galactocerebrosidase (GALC) cDNA and gene and identification of the mutation causing globoid cell leukodystrophy (Krabbe disease) in this primate," Genomics, vol. 42, no. 2, pp. 319-324, 1997. 
[42] B. A. Salau, O. Osilesi, G. O. Idowu, S. Musa, and E. O. Ajani, "Effects of fruits and vegetables on cardiovascular disease risk factors in non-insulin dependent diabetes mellitus (NIDDM) subjects," African Journal of Medical and Pharmaceutical Sciences, vol. 7, pp. 21-26, 2003.

[43] A. M. L. Dans, M. V. C. Villarruz, C. A. Jimeno et al., "The effect of Momordica charantia capsule preparation on glycemic control in Type 2 Diabetes Mellitus needs further studies," Journal of Clinical Epidemiology, vol. 60, no. 6, pp. 554-559, 2007.

[44] A. Eidi, M. Eidi, and M. Sokhteh, "Effect of fenugreek (Trigonella foenum-graecum L.) seeds on serum parameters in normal and streptozotocin-induced diabetic rats," Nutrition Research, vol. 27, no. 11, pp. 728-733, 2007.

[45] S. K. Rashmi and D. Kumar, "Antidiabetic effect of Euphorbia hirta leaves in alloxan induced diabetic mice," Pharmacologyonline, vol. 1, pp. 61-69, 2010.

[46] S. Ahmed, M. A. Awal, M. M. Rahman, and M. Mostofa, "Comparative efficacy of neem and karela with insulin and glibenclamide on biochemical parameters in rabbit," Journal of Animal and Veterinary Advances, vol. 4, no. 2, pp. 221-223, 2005.

[47] P. D. Mayne, "Lipid metabolism," in Clinical Chemistry in Diagnosis and Treatment, pp. 240-243, Clays publisher, London, UK, 6th edition, 1993.

[48] J. Virdi, S. Sivakami, S. Shahani, A. C. Suthar, M. M. Banavalikar, and M. K. Biyani, "Antihyperglycemic effects of three extracts from Momordica charantia," Journal of Ethnopharmacology, vol. 88, no. 1, pp. 107-111, 2003.

[49] A. Aloulou, K. Hamden, D. Elloumi et al., "Hypoglycemic and antilipidemic properties of kombucha tea in alloxan-induced diabetic rats," BMC Complementary and Alternative Medicine, vol. 12, article 63, 2012.

[50] N. Hfaiedh, J .C. Murat, and A. Elfeki, "Diabetes-induced damages in rat kidney and brain and protective effects of natural antioxidants," Journal of Nutrition \& Food Sciences, vol. 3, no. 4, 2013.

[51] M. G. Moghaddam, I. Ansari, M. Roghani, and M. Moradi, “The Effects of Origanum Majorana on oxidative stress and histopathology of renal tissue among streptozotocin-induced diabetic rat," Thrita Journal of Medical Sciences, vol. 2, no. 1, pp. 29-34, 2013.

[52] A. C. Guyton and J. E. Hall, Textbook of Medical Physiology, WB Saundersp, Philadelphia, Pa, USA, 10th edition, 2000.

[53] G. L. Bakris, "Diabetic nephropathy: What you need to know to preserve kidney function," Postgraduate Medicine, vol. 93, no. 5, pp. 89-93, 1993.

[54] T. Tuvemo, U. Ewald, M. Kobbah, and L. A. Proos, "Serum magnesium and protein concentrations during the first five years of insulin-dependent diabetes in children," Acta Paediatrica, International Journal of Paediatrics, Supplement, vol. 86, no. 418, pp. 7-10, 1997.

[55] N. Makare, S. Bodhankar, and V. Rangari, "Immunomodulatory activity of alcoholic extract of Mangifera indica L. in mice," Journal of Ethnopharmacology, vol. 78, no. 2-3, pp. 133-137, 2001.

[56] T. P. Almdal and H. Vilstrup, "Strict insulin therapy normalises organ nitrogen contents and the capacity of urea nitrogen synthesis in experimental diabetes in rats," Diabetologia, vol. 31, no. 2, pp. 114-122, 1988.

[57] A. Bener, M. Zirie, and A. Al-Rikabi, "Genetics, obesity, and environmental risk factors associated with type 2 diabetes," Croatian Medical Journal, vol. 46, no. 2, pp. 302-307, 2005.
[58] J. L. Evans, I. D. Goldfine, B. A. Maddux, and G. M. Grodsky, "Oxidative stress and stress-activated signaling pathways: a unifying hypothesis of type 2 diabetes," Endocrine Reviews, vol. 23, no. 5, pp. 599-622, 2002.

[59] R. Rahimi, S. Nikfar, B. Larijani, and M. Abdollahi, "A review on the role of antioxidants in the management of diabetes and its complications," Biomedicine and Pharmacotherapy, vol. 59, no. 7, pp. 365-373, 2005.

[60] Y. Y. Soon and B. K. H. Tan, "Evaluation of the hypoglycemic and anti-oxidant activities of Morinda officinalis in streptozotocin-induced diabetic rats," Singapore Medical Journal, vol. 43, no. 2, pp. 77-85, 2002.

[61] D. Sathishsekar and S. Subramanian, "Antioxidant properties of Momordica Charantia (bitter gourd) seeds on Streptozotocin induced diabetic rats," Asia Pacific Journal of Clinical Nutrition, vol. 14, no. 2, pp. 153-158, 2005.

[62] X.-F. Zhang and B. K.-H. Tan, "Antihyperglycaemic and antioxidant properties of Andrographis paniculata in normal and diabetic rats," Clinical and Experimental Pharmacology and Physiology, vol. 27, no. 5-6, pp. 358-363, 2000.

[63] A. Kalaivani, A. Umamaheswari, A. Vinayagam, and K. Kalaivani, "Anti-hyperglycemic and antioxidant properties of Cassia auriculata leaves and flowers on alloxan induced diabetic rats," Pharmacologyonline, vol. 1, pp. 204-217, 2008. 

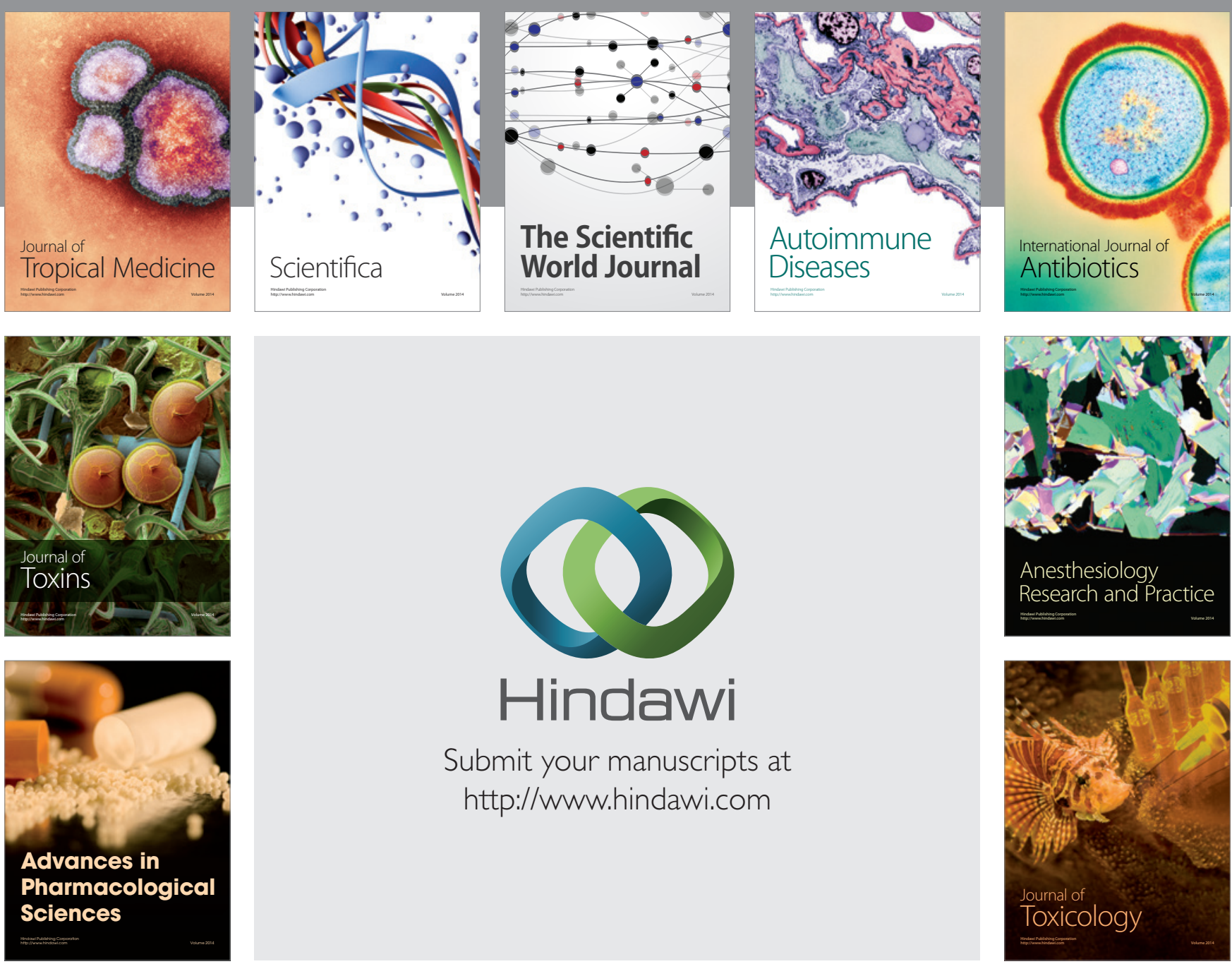

\section{Hindawi}

Submit your manuscripts at

http://www.hindawi.com
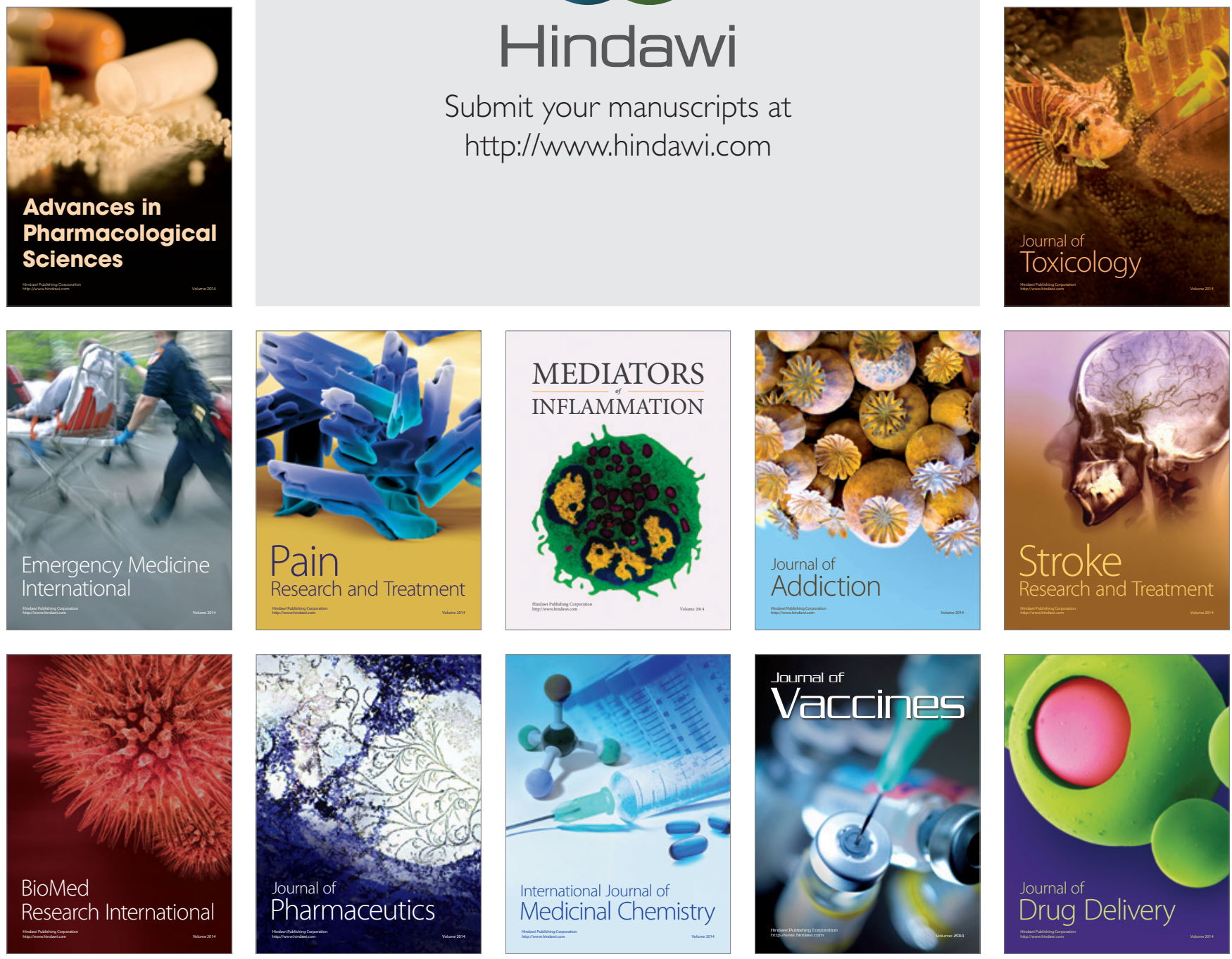